\title{
What is «Critique of Worldmaking»? Nelson Goodman's Conception of Philosophy
}

\author{
Lars Leeten \\ Universität Hildesheim \\ leeten@uni-hildesheim.de
}

\begin{abstract}
The contribution examines Goodman's conception of philosophy, in particular his remark that his project can be understood as a "critique of worldmaking». It is argued that, despite dealing with epistemological questions, the general theory of symbols and worldmaking does not answer them. Rather, it can be conceived as a practical conception comparable to Kant's critique of reason or to Wittgenstein's critique of language games, i. e., as a philosophy of world orientation. It is claimed that Goodman himself could not articulate this dimension of his position appropriately as he kept using the language of epistemology. Yet many aspects of his thinking become much clearer if they are interpreted within a non-epistemological frame.
\end{abstract}

Keywords: Goodman; symbol theory; worldmaking; world orientation; world disclosure.

Resumen. ¿Qué es la "critica de la construcción de mundos»? La concepción de la filosofía de Nelson Goodman

Esta contribución examina la concepción de la filosofía de Goodman, concretamente su afirmación de que su proyecto puede entenderse como una "crítica de la construcción de mundos». Se argumenta que, a pesar de tratar cuestiones epistemológicas, la teoría general de los símbolos y de la construcción de mundos no las contesta. Más bien se puede considerar como una concepción práctica comparable a la crítica de la razón de Kant o a la crítica de los juegos del lenguaje de Wittgenstein, esto es, como una filosofía de la orientación del mundo. Se defiende que Goodman no podría haber articulado esta dimensión de su postura de un modo apropiado puesto que siguió usando el lenguaje de la epistemología. Ahora bien, muchos aspectos de su pensamiento son mucho más claros si se interpretan en un marco no epistemológico.

Palabras clave: Goodman; teoría de los símbolos; construcción de mundos; orientación del mundo; apertura del mundo. 


\begin{aligned} \multicolumn{2}{c}{ Summary } \\ $\begin{aligned} \text { 1. Introduction } & \text { 4. The language of representation } \\ \text { 2. Constructionalism and the idea } & \text { 5. Beyond representation } \\ \text { of mapmaking } & \text { References } \\ \text { 3. Worldmaking as mapmaking } & \end{aligned}\end{aligned}$

\section{Introduction}

In Ways of Worldmaking, Nelson Goodman describes his philosophical project as a critique of worldmaking. "Worlds are made by making [...] versions with words, numerals, pictures, sounds, or other symbols of any kind in any medi$\mathrm{um}$; and the comparative study of these versions and visions and of their making is what I call a critique of worldmaking» (WW, 94). Elsewhere Goodman says that his «main undertaking [...] is examination and comparison of the ways we make what we make - call them versions or worlds as you like - and of the criteria we use in judging what we make» $(M M, 43)$. - What does the label «critique of worldmaking» exactly mean? What is the conception of philosophy Goodman has in mind? And how do we have to interpret his general symbol theory if it is primarily a critique of worldmaking?

It is tempting to think that "critique of worldmaking» is just a different label for «epistemology», only that its scope is broader. One basic assumption of this article, though, is that Goodman is not engaged in epistemology at all, at least not in the usual sense. The question is not whether epistemology has to be conceived narrow or broad. Symbol theory is not so much a theory but rather a practical conception, a certain technique of thinking. This might seem rather far-fetched at first sight, as Goodman more than once emphasizes that a philosopher «is driven not by practical needs but by an impractical desire to understand» $(P P, 169)$. Even though he discovers language practice as a fundamental point of reference in his theory of induction (especially, FFF, 4.34.4), he never takes into account the details of the pragmatic dimension of sign use and everyday language (Goodman, 1996, 205). His refusal to go into questions of ethical rightness ( $W W, 109$, Fn. 1) only underlines a general lack of normative discussion in Goodman's work. Therefore one is inclined to perceive his "general theory of understanding» $(R, 53)$ as a general theory of knowledge, an extended epistemological conception concerned with «understanding or cognition in all of its modes» $(R, 4)$. Accordingly, rightness is taken to be Goodman's epistemological criterion, representing the standard to separate acceptable from inacceptable world descriptions. Rightness takes the place of truth, only that it is, "unlike truth, $[. .$.$] multidimensional» (R, 156)$. The expressions may have changed, but the project is still the same.

Here, this perspective is called into question. Goodman, to be sure, uses the vocabulary of epistemology and he starts with the problems of epistemol- 
ogy. Still, many elements of his thinking become much clearer if they are interpreted in a frame beyond epistemology. His philosophy is done more justice if one presupposes that it does not answer to epistemological questions. In order to show this, I will first examine some of Goodman's early general considerations on philosophy, in particular the idea of constructional systems (2). Second, I will try to develop my thesis in the context of his later philosophy of symbols and worldmaking (3). Finally I will come back to the question of epistemology (4) and try to give an alternative account of what «critique of worldmaking» might mean (5). My claim will be that this label points into the direction of a practical reflection comparable to Kant's critique of reason or to Wittgenstein's critique of language games, i. e., as a philosophy of world orientation and world disclosure under the conditions of finiteness - a claim which, of course, does not include a "truth about Goodman», but only suggests a certain way of categorization.

\section{Constructionalism and the idea of mapmaking}

Goodman's philosophical work contains many issues from quite diverse fields like ontology, logic, epistemology, symbol theory and aesthetics. It would be difficult to extract his conception of philosophy from this starting point. So what does he say about his notion of philosophy?

In the final chapter of Reconceptions in Philosophy and Other Arts and Sciences, under the heading "A Reconception of Philosophy", we find the idea of a three-staged undertaking that starts with the examination of symbols, then turns to their constitutive meaning for world disclosure, and finally results in a revision of philosophy $(R, 164)$. The considerations of Languages of Art, then, could be the first step of a project that continues with Ways of Worldmaking, and ends with the outline of a new notion of philosophy. This notion, though, is presented as a certain epistemological position called "constructionalism» $(R, 166)$. In the following, I claim that Goodman's thinking implicitly suggests a much more radically revised conception of philosophy. Indeed, the label «epistemology» is misleading here, as the philosophy of worldmaking should better be interpreted as a conception presupposing a primacy of practice. In order to show this, though, we have to go back to The Structure of Appearance and Problems and Projects.

One of the main motives in Goodman's early work is his repudiation of the ideas of certainty and immediacy. The position that becomes apparent in The Structure of Appearance seems to be the result: Goodman obviously rejects any epistemological foundationalism in favor of an epistemological stance called phenomenalism. But the second sight shows that things are slightly more complicated. Goodman does develop a phenomenalistic system in his early work. Yet this does not mean that he supports phenomenalism as the right system of epistemology. Indeed, in the introduction to The Structure of Appearance it is underlined that the frame of the conception is the theory of constructional systems which includes strong relativist and pluralist assumptions, in 
particular the assumption that phenomenalism is only one of many possibilities of reconstruction ( $S A$, il-l). His conception must not be taken as an immediate expression of Goodman's philosophical standpoint. He does not want to explain the world or give a fundament to knowledge. His aim is to systematize knowledge. The phenomenalist conception is rather an example of the philosophical stance Goodman takes. From the viewpoint of the phenomenalist theory, the basic assumptions of this position are part of a metatheory (Hellmann 1977, xxvi f and $S A, 1)$.

What we have to ask, then, is what this metatheory, namely the theory of constructional systems implies. Goodman develops this theory in the first part of The Structure of Appearance. A constructional system is a system of constructional definitions, i. e., of definitions «introduced for explanatory purposes» ( $S A$, 3). Unlike a notational definition, a constructional definition defines everyday or presystematic expressions while preserving their original interpretation. It serves to clarify the presystematic domain by reaching both economy (a reduction of primitive terms) and a systematic order $(S A, 47 \mathrm{f})$. "To economize and to systematize are the same» $(S A, 48)$. In order to serve this purpose, a constructional definition does not only have to fulfill formal requirements: «A constructional definition is correct - apart from formal considerations - if the range of application of its definiens is the same as that of the definiendum. Nothing more is required than that the two expressions have identical extensions» $(S A, 3)$. This, in turn, calls for what Goodman labels «extensional isomorphism» $(S A, 10)$. The picture that is construed does not simply reflect the presystematic domain. But still it is restricted to the applications which are generally accepted as right in the original symbolic practice.

In «The Revision of Philosophy» Goodman explains this method as a matter of mapping: "The function of a constructional system", he writes, «is not to recreate experience but rather to map it» $(P P, 15)$. Consequently, in a constructional definition the symbol «=df» is to be read as «is here to be mapped as» $(P P, 18)$. Here we get a distinct idea of Goodman's way of systematizing: to systematize is to simplify and organize a given domain for the sake of clarification: The purpose of a system is not to represent the world (to make knowledge available) but to arrange what we already know (to make knowledge serviceable). A map would be useless if it copied the world; and likewise, a mere reproduction of the world is no reasonable aim. Goodman describes the function of a map as follows:

A map is schematic, selective, conventional, condensed, and uniform. And these characteristics are virtues rather than defects. The map not only summarizes, clarifies, and systematizes, it often discloses facts we could hardly learn immediately from our explorations. We may make larger and more complicated maps or even three-dimensional models in order to record more information; but this is not always to the good. For when our map becomes as large and in all other respects the same as the territory mapped - and indeed long before this stage is reached - the purposes of a map are no longer served. $(P P, 15)$ 
A map does not grasp what is already there. A good map systematizes a field and contributes to its disclosure. It delivers a perspective that allows us to deal with things; i. e., it brings a world into sight. So a map is a medium of world orientation. And insofar as mapping is the central goal of Goodman's philosophy, it is a philosophy of world disclosure and world orientation: It aims not at understanding the world in the first place, but at understanding our own ways of understanding ( $W W, 21 \mathrm{f})$. Therefore it is justified to say that Goodman's conception of philosophy is close akin to Wittgenstein's conception of philosophy as grammar. Goodman's idea of «mapmaking» can be interpreted as a variation of Wittgenstein's idea of übersichtliche Darstellung - a term which can roughly be translated as surveyable representation ${ }^{1}$. In the conception of language games, the aim is to find representations that allow us to «know our way about» ${ }^{2}$. Likewise, Goodman's philosophy of mapmaking does not aim at «a portrayal of the process of acquiring knowledge» or «the genesis [...] of ideas» $(P P, 10)$. The criterion of truth does not apply: «The relevant question about a system or a map is whether it is serviceable and accurate in the way intended» $(P P, 16)$.

Below, I suggest that the conception of mapmaking reaches into Goodman's later thought which hence can be interpreted as a project of surveyable representation in the sense described. In the philosophy of worldmaking, symbols are taken as a condition of understanding: They neither grasp the world in itself nor obscure the sight, but make world views possible. Symbols constitute the perspectives that allow reality to come into sight. In a slogan: Worldmaking is mapmaking.

\section{Worldmaking as mapmaking}

At first sight, it seems that constructional systems got lost in the later general theory of symbols, as developed in Languages of Art. In actual fact, though, symbol systems are descendants of constructional systems. Just as the metatheory of The Structure of Appearance demands, a symbol system includes both its symbols and its interpretation ( $L A, 40$ and Hellman 1977, $\mathrm{XX}$ ). It is not an institution waiting to be described but a result of a reconstruction - i. e., one reconstruction out of many. Also, Goodman's tendency to look down on everyday symbolic practice appears in quite a different light, given the purpose of his philosophizing. He does not ignore the

1. Cf. Wittgenstein 1953, $\$ 122$. The expression «übersichtliche Darstellung» produces a problem for any translation. Anscombe's «perspicuous representation» has lately been replaced for «surveyable representation» by Hacker and Schulte: cf. Wittgenstein 2009, 252. The translation «bird's eye view» - cf. Wittgenstein 1975, I.1 — is clearly wrong; and as far as «synoptic overview» points into the same direction it is no less problematic. In fact, «Darstellung» alone is hard to translate as it is opposed to "Vorstellung» which corresponds to «representation». - Later, I will come back to this issue.

2. Cf. Wittgenstein 1953, $\$ 123$ : «Ein philosophisches Problem hat die Form: Ich kenne mich nicht aus.» ("A philosophical problem has the form: I don't know my way about.») 
pragmatic or social dimension of sign use. Indeed this dimension is always present in the background. Only, his relation to everyday practice is determined by the purpose of clarification.

In Goodman's later work this methodology — the more developed form of the metatheory of The Structure of Appearance - often goes under the heading of nominalism. This label has given rise to many misunderstandings as it has regularly been interpreted as an epistemological or even metaphysical stance ${ }^{3}$. However, Goodman emphasizes again and again that his nominalism has a methodological sense. In his early writings we find the explanation that nominalism «does not involve excluding abstract entities, spirits, intimations of immortality, or anything of the sort; but requires only that whatever is admitted as an entity at all be construed as an individual» (PP, 157, emphasis added $)^{4}$. So the concept of nominalism, here, has no ontological sense at all, it concerns the method of reconstruction exclusively; it is a technique. The idea is: In order to systematize well one should restrict oneself to individual elements ${ }^{5}$. What looks like ontology at first sight turns out to be a rule of thumb for clarification purposes - a rule, by the way, to which Goodman more than once makes exceptions ( $L A$, xiii).

So the explanations of nominalism in Languages of Art or Ways of Worldmaking have an exclusively methodological sense. They are usually short, and Goodman more or less contents himself with reference to his earlier writings ( $L A, 156$; $W W, 10,94-96$ and 100f; $M M, 29 f)$. This might be one of the reasons why his nominalism has so often been mistaken for a metaphysical doctrine. However, many elements of Goodman's late pluralism become nearly unintelligible if one loses sight of its basic methodology and its practical purpose. The debate about starmaking (McCormick 1996, Scheffler 1999, Scheffler 2001) can serve as an example: It seems fair to discuss how a radical pluralism like Goodman's can ever be justified; to many it seems that the idea of a "pluriverse» is completely counterintuitive and has to provoke realist rejoinders. But a closer look shows that the whole debate might be beside the point: Goodman's pluralism does not have an ontological sense at all, it does not want to be a "sweeping general doctrine» $(M M, 43)$. It is hardly ever noticed how peculiar Goodman's contributions to this subject are: «I by no means insist that there are many worlds - or indeed any», he writes in Ways of Worldmaking ( WW, 96). There is no fixed number of symbol worlds as a world is regarded as actual if a world description is recognized as right (WW, 94).

3. Shottenkirk (2009) argues that to understand Goodman's philosophy one has to read Goodman's work as a whole. In particular, the nominalism of The Strucure of Appearance had to be accounted for. For Shottenkirk, though, this means that Goodman's "Metaphysics is an explication of Goodman's basic nominalist ontology and logic, and it is upon those principles that he builds his epistemology» (ibid., vii).

4. A bit further it says: «To explain nominalism we need to explain not what individuals are but rather what constitutes describing the world as composed of them» $(P P, 159)$.

5. This is why Scheffler can speak of inscriptionalism instead: cf. Scheffler 1997, 6f. Also cf. $S A, 46$. 
Irrealism, Goodman says, «is not one more doctrine [...] but is rather an attitude of unconcern with most issues between such doctrines» ( $M M, 43$; Goodman 1996, 203f). Similarly, Goodman defends irrealism against Putnam's "commonsense realism» only insofar as «irrealism can by no means brook any acceptance of commonsense at face value but at most as only presystematic discourse urgently requiring critical examination and organization into wellmade versions» (Goodman 1996, 205). Obviously, the idea of constructional systems is in the background here, and indeed the passage includes a reference to Goodman's early work.

It should have become clear by now that Goodman's later philosophy is still deeply informed by the early idea of constructional systems. It is not so much a doctrine, a theory, but rather a technique of clarification, a practice that I suggest to call practice of perspicuous representation. In the following sections I will ask for some implications of this approach. My assumption is that some of the difficulties to do justice to Goodman's project derive from the fact that he himself keeps using the language of epistemology. I will first make some remarks on the topic of epistemology in general and after that make a suggestion how to understand the term "critique of worldmaking».

\section{The language of representation}

In his paper "A world of individuals» Goodman writes that the philosopher's «task is to interrelate, systematize, interpret, explain». Then he continues as follows: «He [sc. the philosopher] is driven not by practical needs but by an impractical desire to understand. He, too, will judge a system by how well it works; but a system works for him only to the extent that it clarifies» (PP, 169). Similarly, in Languages of Art, Goodman says, that the "primary purpose» of symbolizing was "cognition in and for itself». In this context, any practical, in particular communicative purposes are excluded: «[...] communication is secondary to the apprehension and formulation of what is to be communicated" $(L A, 258)$. - So rhetorically, the weight is clearly put on the cognitive dimension. The crucial point is: Goodman himself tends to describe his technique of world orientation by using the terms of epistemological theory.

This is what I want to discuss. Is it plausible to understand a project like Goodman's as an epistemological project? The critique of theory of knowledge in general is known since Hegel's Phenomenology of Spirit and has been carried forward by authors like Heidegger, Wittgenstein or Merleau-Ponty. The problems are especially obvious in the case of foundationalism. But one might have a suspicion that this is only the tip of the iceberg: In this spirit, Charles Taylor claims that epistemology does not have to be «overcome» in its foundationalist form only as the core of the problem is the representationalism implied in the idea of a theory of knowledge (Taylor 1987, 9f). According to Taylor, the critique of epistemology has its fundament in the rejection of the modern premise that there are «ideas» that have intentional content and point to the world, whereas Kant shows that it is unintelligible how anything could have 
these properties all at once. Knowledge cannot be separated from practical standpoints, it has its ultimate fundament in the «agent's knowledge» (Taylor $1987,10 \mathrm{f})$. But if this is right, then the idea of epistemology becomes problematic as such. The idea of privileged representations mirroring the world is not specifically foundationalist, like Rorty suggests; it is not restricted to the ideology of knowledge atoms (Rorty 1979). In actual fact, the possibility to differentiate wrong and right representations from a privileged standpoint beyond human practice is blocked in general. If epistemology is an attempt to catch up with everyday epistemic judgments, to solve the question of reliable knowledge by theory, then epistemology has come to an end. At the bottom of world representations we will not find world representations more fundamental, but inarticulate human practice (Taylor 1987, 14). This practice, though — this is one of the central insights in the late Wittgenstein - can neither be overviewed nor reproduced in theory as it is subtle and fine-spun as a spider's web (Wittgenstein 1953, $\$ 106$ ). This is why we cannot distance ourselves from our own being-in-the-world, as expressed in the language of phenomenology. The only thing we can ask for is an analysis for the purpose of orientation and disclosure. The basic mistake of representationalist epistemology is that it does ask for more. But in fact, we cannot judge world descriptions from a scientific, unengaged position. Philosophy cannot deliver fixed criteria but only help to make considered judgments, invent concepts, explicate the background of knowledge, help us to know our way about. Its task is not to represent cognitive processes but to make maps within the practice of understanding. All we can do is to support epistemic practice.

If this is what Goodman does - if it is right to describe his project as one of making maps and surveyable representations - then his emphasis on the "primacy of cognition" is wholly misleading. The primacy of clarification includes a primacy of human practice and its purposes. When Goodman describes his philosophy as "examination and comparison of the ways we make what we make $[. .$.$] and of the criteria we use in judging what we make» ( M M$, 43), he cannot take a standpoint outside practice but only within. The notion of symbol, introduced as a "very general and colorless term» ( $L A, \mathrm{xi})$, should then be taken as a philosophical instrument that does not refer to representations of reality or even «ideas» in Locke's sense. In particular, it does not serve to differentiate right renderings from wrong ones ${ }^{6}$. The German «Darstellung» that Wittgenstein uses can help to grasp this point. Unlike the term «Vorstellung» (usually corresponding to «representation»), «Darstellung» refers to a practice of the forming presentations that has standards of its own and is not bound to given facts whatsoever. This explains why the criteria of rightness that Goodman mentions - e. g., correctness, coherence, purposefulness and «along with truth, standards of acceptability that sometimes supplement or even com-

6. This is especially obvious in the fact that Goodman never describes criteria to sort out wrong symbolizations. Rather, whenever he speaks of world versions he speaks of right symbolizations. $L A, 3 \mathrm{f}$. 
pete with truth where it applies, or replace truth for nondeclarative renderings» (WW, 110) - cannot count as epistemological standards but are criteria "we use», i. e., criteria of everyday's human practice.

The assumption of «multiple actual worlds» (WW, 2, emphasis added) which is central to Goodman's pluralism relates to an assumption of a variety of symbolic practices with specific rules and criteria that the philosopher can never hope to exhaust. One might say: Human practice is no subject in Goodman's philosophy as he does not distance himself from practice but adopts a practical standpoint. His attempt is to clarify practice from a standpoint of finiteness. In the last section, I examine the project of a critique of worldmaking in this sense a bit more closely. It has already been shown that Goodman's project can be read as a conception of world disclosure (Ortland 2001, Seel 1993). I will focus on the idea of critique as a matter of world orientation.

\section{Beyond representation}

Goodman's thinking can be understood as an effort of mapping, built upon a method of übersichtliche Darstellung. One could say: His philosophy of worldmaking is a philosophy of world orientation in the corset of epistemology. But as the idea of looking at the epistemic practice from the side is dropped, the aim can no longer be to find "privileged representations". Rather, it is an attempt to clarify the ongoing practice in order to support "considered judgments" (Elgin 1996). The purpose of Goodman's philosophy is orientation and clarification. In this respect, his philosophy is close to Wittgenstein's and, maybe less obviously, to Kant's.

Kant's thinking is motivated by the observation that the world cannot be experienced as a totality, that the unity of the whole can only be an «idea». The antinomy of the two perspectives of freedom and nature is the most well known motive in this context; it is the starting point of Kant's philosophy. The result is not a theory but a critique of knowledge: i. e., a differentiation of domains of judgments, each having its own rules and criteria ${ }^{7}$. Such an approach does not aim at epistemology but at an orientation in thinking ${ }^{8}$.

If the notion of a "critique of worldmaking" has a Kantian sense, then it should be possible to find, at least, hints into this direction. Indeed, Goodman's «irreconcilable conflict of world versions» plays quite a similar role as Kant's antinomy ${ }^{9}$. It is the starting point that opens up a critical (as opposed to metaphysical) perspective: Goodman's turn from truth to rightness does not only derive from a modification of standards. It implies, before all, a pluraliza-

7. The most radical interpretation of this Kantian thought is to be found in Jean-François Lyotard's Le Différend. It would be interesting to compare Lyotard's account of a différend to Goodman's account of irreconcilable conflicts: Lyotard 1983, 9 and WW, 109-116. For an attempt see Leeten 2010, 243-248.

8. This aspect in Kant's philosophy is developed in Kant (1786): «Was heißt: sich im Denken orientieren?».

9. Cf. WW, Ch. VII and, with reference to Kant's antinomies, MM, 32. 
tion of standards and the idea of a multitude of domains. But where a plurality of criteria is allowed, the standards of science are some among many others and the philosopher loses his privileged position. Which standards have to be applied cannot be decided by reflection alone - like any vote for a particular metaphysical stance, e. g., Quine's vote for physicalism (Quine 1981), seems to presuppose. The conflict between monism and pluralism, here, is not simply a conflict of two epistemological approaches; it is a conflict between an epistemological approach and an approach that does not claim privileged knowledge any longer but has become a part of human practice. Philosophy, then, does not serve the purpose of discovering truths about the world but rather of handling our understanding of the world.

Considering that this account is right: The general theory of symbols then should indeed better be understood as a practical conception, akin to positions of world orientation or world disclosure. Many aspects of Goodman's thinking should become clearer if interpreted in a non-epistemological frame. But this is not all: If Goodman's philosophy is a philosophy of practice in the sense described, then it has its value not in itself. The crucial question would be what we make of $i$. As a system of categorization the symbol theory would be a means of thinking, namely an instrument for clarification purposes, and its value would show itself in its use alone. Goodman himself writes: «For a categorical system, what needs to be shown is not that it is true but what it can do" (WW, 129). The general theory of symbols is a categorical system. So the question cannot be whether it is a true doctrine but what we can do with it. Such a reception of Goodman's philosophy is still to be explored.

\section{References}

Elgin, Catherine Z. (1996). Considered Judgment. Princeton, N.J.: Princeton University Press.

Goodman, Nelson (1951). The Structure of Appearance. 3rd Edition, Dordrecht, Boston: Reidel, 1977.

- (1954). Fact, Fiction and Forecast. London: Athlone.

- (1968). Languages of Art. An Approach to a Theory of Symbols. Second Edition. Indianapolis, Cambridge: Hackett, 1999.

- (1972). Problems and Projects. Indianapolis, New York: Bobbs-Merrill.

- (1978). Ways of Worldmaking. Indianapolis: Hackett, 1999.

- (1984). Of Mind and Other Matters. Cambridge, London.

- (1996). "Comments». In: McCormick, Peter J. (ed.), Starmaking: Realism, Anti-Realism and Irrealism. Cambridge, Mass.: MIT Press, 203-213.

Goodman, Nelson and Elgin, Catherine Z. (1988). Reconceptions in Philosophy and Other Arts and Sciences. Indianapolis: Hackett.

Hellman, Geoffrey (1977). «Introduction». In: Goodman, Nelson. The Structure of Appearance. $3^{\text {rd }}$ Edition, Dordrecht, Boston: Reidel Publishing, XIX-XLVII. 
Kant, Immanuel (1781/1787). Kritik der reinen Vernunft. Werke III-IV, Darmstadt: Wissenschaftliche Buchgesellschaft 1983.

- (1786). «Was heißt: sich im Denken orientieren?». Werke V, Darmstadt: Wissenschaftliche Buchgesellschaft 1983, 267-283.

LeETEn, Lars (2010). Zeichen und Freiheit. Über Verantwortung im theoretischen Denken. Bielefeld: transcript.

Lyotard, Jean-François (1983). Le différend. Paris: Les Éditions de Minuit.

McCormick, Peter J. (ed.) (1996). Starmaking: Realism, Anti-Realism and Irrealism. Cambridge, Mass.: MIT Press.

OrtLand, Eberhard (2001). «Ästhetik als Wissenschaft der sinnlichen Erkenntnis. Ansätze zur Wiedergewinnung von Baumgartens uneingelöstem Projekt». Deutsche Zeitschrift für Philosophie, 49/2, 257-274.

Quine, Willard Van Orman (1981). "Goodman's Ways of Worldmaking». In: Theories and Things. Cambridge, Mass.: MIT Press, 96-99.

Rorty, Richard (1979). Philosophy and the Mirror of Nature. Princeton: Princeton University Press.

Scheffler, Israel (1997). Symbolic Worlds. Art, science, language, ritual, Cambridge, Mass.: Cambridge University Press.

- (1999). «A Plea for Plurealism». Transactions of the Charles S. Peirce Society, 35, 425-436.

- (2001). «My Quarrels with Nelson Goodman». Philosophy and Phenomenological Research, 92, 665-677.

SeEL, Martin (1993). «Über Richtigkeit und Wahrheit. Erläuterungen zum Begriff der Welterschließung». Deutsche Zeitschrift für Philosophie, $41 / 3,509-524$.

ShotTenkirk, Dena (2009). Nominalism and Its Aftermath. The Philosophy of Nelson Goodman, Dordrecht/Heidelberg/London/New York: Springer.

Taylor, Charles (1987). «Overcoming Epistemology». Philosophical Arguments. Cambridge, Mass./London: Harvard University Press 1995, 1-19.

Wittgenstein, Ludwig (1953). Philosophische Untersuchungen. Frankfurt/ Main: Suhrkamp 1984, 225-618. Here cited: Philosophical Investigations, ed. by P.M.S. Hacker and J. Schulte, Oxford: Blackwell, 2009.

- (1975). Philosophical Remarks. RheEs, Rhush (ed.). Oxford: Blackwell. 
Lars Leeten studied philosophy, literature and semiotics in Osnabrück and Berlin. He earned his Ph.D. in philosophy from the TU Berlin, where he taught philosophy from 2007 to 2009. Since 2008 he is a postdoctoral research assistant at the University of Hildesheim, Germany. In 2009 he was a visiting professor at the UFPA in Belém (Brasil); in 2010 he held a guest lectureship at the IUC Dubrovnik. His current fields of interest include philosophy of language, ethics, social philosophy, and rhetoric. Among his publications are: Zeichen und Freiheit. Über Verantwortung im theoretischen Denken (2010); «Peaceful Agreement. Some Thoughts about the Practice of Peace» (2010); «Wen meine ich, wenn ich 'wir' sage? Elemente der Ersten Person Plural» (2011).

Lars Leeten estudió filosofía, literatura y semiótica en Osnabrück y Berlín. Obtuvo su doctorado en filosofía de la TU Berlin, donde impartió clases de filosofía de 2007 a 2009. Desde 2008 es asistente postdoctoral de investigación en la Universidad de Hildesheim, Alemania. En 2009 fue profesor visitante en la UFPA in Belém (Brasil); en 2010 fue lector invitado en el IUC Dubrovnik. Sus campos de interés incluyen la filosofía del lenguaje, ética, filosofía social y retórica. Entre sus publicaciones destacan: Zeichen und Freiheit. Über Verantwortung im theoretischen Denken (2010); "Peaceful Agreement. Some Thoughts about the Practice of Peace» (2010); «Wen meine ich, wenn ich 'wir' sage? Elemente der Ersten Person Plural» (2011). 